\title{
The Effectiveness a Role of the Ombudsman's Makassar
}

\author{
Juharni \\ Rahmat \\ Haedar Akib \\ Universitas Negeri Makassar, Indonesia, Jln. Bonto Langkasa Kampus Gunung Sari Baru, Postal Code 90222 \\ arni.guntur@yahoo.com, rakhmat20@gmail.com, haedar652002@yahoo.com
}

\section{Doi:10.5901/mjss.2016.v7n3p229}

\section{Abstract}

This study aims to determine the effectiveness of the Ombudsman's (a government appointee who investigates complaints by private persons against the government) role Makassar through analysis of, 1) the readiness of the ombudsman Makassar to receive reports or complaints from the public, 2) the strategy pursued by the ombudsman city of Makassar in following up on public complaints 3) quality of service of government agencies to the community after complaint ombudsman to the city of Makassar. The research method used is descriptive research qualitative, whereas the approach used is phenomenological. The informants are the Ombudsman Commissioner Makassar, assistant commissioner, Commissioner of staff, agency or local work units (SKPD) reported and the reporting community. From the results of this research is that Commissioner Ombudsman Makassar, has been carrying out its duties as a supervisor of public services by receiving reports from the public on violations committed by government agencies (SKPD) and then follow up by providing recommendations to the agency or a report to city government (Mayor of Makassar) with the aim of to improve the performance of SKPD its unfavorable. Thus, Ombudsman Makassar showed effectiveness in carrying out the role, tasks, and functions.

Keywords: effectiveness, the role of ombudsman.

\section{Introduction}

To follow and evaluate the performance of the public service, in every government institution (SKPD). Internally, there is local government supervisory agency called oversight body area (BAWASDA) or the regional inspectorate. The agency is tasked to supervise and control the internal implementation of the tasks of local government agencies according to the decision mayors / Regents. Although this institution has been carrying out its role, but its existence was rated by many people still have limitations or shortcomings because they often intervened by public officials in carrying out their duties, besides that the Institute still has other limitations, namely lack of space for the community (public) to participate control and supervise the running of the government in a systematic and continuous. (Patarai: 2010, p. 3).

Public complaints over the discontent they received not accommodated in the tasks of a regional inspectorate, so that people do not have access to scrutinize or monitor the running of the government, so that it is considered to give less meaning to the local government system that is decentralized (local autonomy) because of the involvement community in controlling the running of the government still tends to be low.

To increase public participation in the control or supervision of the government's performance or SKPD, the Makassar city government has established an external oversight body that is independent and is named Ombudsman Makassar (OKM) through a regulation mayor (Perwali) No. 7 of 2008, Ombudsman Makassar duty and function, including: serving, follow-up reports and the business community about maladministration unethical and contrary to the law, to help resolve public complaints against public service delivery, (Hand Book, 2009).

Since the establishment of the Ombudsman of Makassar on 11 March 2009 until December 2012, has handled 1235 reports / complaints of society, the number of reports as mentioned above, cannot be used as the performance parameters of the Ombudsman Makassar is good, because it may be an increasing number of issues are dealt with as indeed the increasing number of cases of maladministration that occurred in the middle of the community. In order to improve the service in the public sector and the private sector. Although the number of complaints from the public is increasing, not all the problems followed up by the ombudsman Makassar, because it is beyond the authority of the Ombudsman of Makassar, so the solution submitted to any other authorized or not followed up because the complainant 
did not meet the requirements that have been determined.

Of the total complaints over four years of age Ombudsman Makassar, after in-depth observed turned out to government agencies was recorded as the institution most widely reported in the city of Makassar includes departments, agencies in the ranks of the municipal government of Makassar with a total of 415 cases. While in the private sector is the field of banking and finance and business firms in the sphere of local government as much as 105 cases of Makassar.

In some object, other public services are still often encountered by people the lack of accountability by agents of public servants, such as water process services through PDAM Makassar, which tends to slow; favoritism is not transparent and prone to extortion. Handling the letter's land ownership (land certificate) through the National Land Agency (BPN) is still slow, the maintenance taxes on land and buildings are convoluted. (Observations in 2013)

Of the above conditions, then the question arises why the ombudsman Makassar city that has long been present; its existence has not been actualized to the maximum in the midst of the practice of maladministration in the city of Makassar, whether because of the resources owned by the Institute is limited in terms of competence or limited in terms of quantity or the number of personnel is still lacking or less socialized so that people do not yet know what the duties and functions of the Ombudsman institution, so people are still reluctant to report any complaints about the services provided public officials, or the ombudsman himself were less responsive to receiving each report or complaints from the public.

Based on the above, the researchers felt it was important to do some research if the presence of Makassar City ombudsman can improve public services in the city of Makassar as well as the existence of the Ombudsman DI Yogyakarta, as evidenced by the results of research conducted by Patarai (2010).

Although the research I did certainly different from the research that has been conducted by researchers earlier (Patarai 2010), which in this study focused on the performance of the Ombudsman in Makassar, in addition to the above, researchers want to know determinant factors on the performance of the Ombudsman in the City Makassar. Thus, this study aims to find out what the main cause so that the role and performance of the ombudsman Makassar assessed tend to be less effective in conducting oversight of the public service performed in Makassar. (Koran Sindo Makassar. Nov 2013)

\subsection{Problem Statement}

Formulations of the problem in this research are 1) Readiness ombudsman Makassar to receive reports or complaints from the public, 2) quality of service to the community of government agencies after the complaint to the ombudsman Makassar

\section{Literature Review}

\subsection{Effectiveness}

In order to make the perception of the amount of definition or understanding of the effectiveness, then the following Ircises oversight of the agency or agencies of public service to the community in Makassar.

\subsection{Ombudsman}

The ombudsman has various definitions; Oxford Dictionary (2007) defines it as an official appointed by the government to investigate public complaints against the authorities and the public service report.

Commission ombudsman is an institution to independently receive and investigate allegations of administrative error (maladministration). Ombudsman role to protect people from rights violations, abuse of power, error, neglect, unfair decision and administrative errors. Through the role of the ombudsman is expected to improve and enhance the performance of public administration, encouraging more open government and accountability can help good governance in the bureaucracy to make it more accountable for society at large. Pope (2003) suggested that the ombudsman was a position independently to accommodate and examine complaints regarding poor public administration services (maladministration).

In Indonesia, the presence of the ombudsman appeared almost simultaneously with the emergence of other independent institutions, though initially had a debate because there is nothing in the article that regulates our basic legislation on these institutions. So at first ombudsman was first established in Indonesia based on Presidential Decree No. 44 of 2000, concerning the National Ombudsman Institute (LON) that is precisely on 20 March 2000. In Chapter II, Article 4 explained that the ombudsman function nationwide is as follows: 1) Disseminating understanding of the 
ombudsman, 2) Coordination and cooperation with government agencies, universities, NGOs, experts, practitioners, professional organizations and others. 3) Perform the steps to follow up reports or information regarding the occurrence of irregularities by the organizers of the State in carrying out its duties and in run the public service. 4) Preparing the concept of a draft law on the national ombudsman.

The ombudsman Makassar is not only directed to oversee the public services provided by the government but also to supervise, ethical business practices. This was stated in the regulations Makassar Mayor Number 7 of 2008, concerning the ombudsman city of Makassar, number of criticisms and suggestions for the violations and the many problems of public services, particularly services carried out by the government of Makassar, through various mass media, this indicated that so many problems faced by the community, so the handling had to be planned by an institution that is judged to have the capacity, competence, and independence of the optimum.

\section{Research Methods}

The method used is descriptive qualitative. Field findings obtained through interviews with several informants who have been determined based on the mastery of research problems and supported the observations of researchers in the field as well as a review of the relevant documentation and literature to address the problems outlined in descriptive studies. The analysis was conducted to determine and describe how the effectiveness of the performance of the Ombudsman Makassar by describing and provide interpretation of the findings.

The reason why writer choose descriptive method because the effectiveness of the role of SMEs is a particular case can not be generalized, requires sensitivity and analytical sharpness and depth of discussion.

\section{Result and Discussion}

\subsection{The role of the Ombudsman in receiving complaints Makassar}

Performance Ombudsman Makassar (OKM) in its function of an institution external oversight that is independent greatly influenced by the extent of the readiness of the device and its members in receiving and processes any reports and complaints that come from the public, the performance of OKM in receipt of the report can be viewed on aspects Source Human power includes staff or personnel readiness and competence of its resources. OKM in accepting the report has no officers or staff on duty to receive reports that have the capability and the ability to receive reports and complaints from the public; however, the Commissioner ombudsman city of Makassar admitted that in terms of quantity is still limited, while the number of problems and complaints are facing more and more, so that this statement be a strong indication that there are no barriers OKM in the availability of personnel in receipt of the report.

Administratively OKM has had the readiness of the format, or the form of the availability of reporting forms were prepared for each complainant. The format includes among others the report number, the date of the report as well as the types of violations reported. The type of offense that is often reported by the public is in the form of a procedural violation, incompetence agencies, intervention, abuse of authority, dereliction of obligation, there is extortion, graft, there are indications of corruption and the slow service, service to the community of discrimination and maladministration other activities.

The process of receiving the report on the Ombudsman Makassar certainly carried out based on Standard Operating Procedures (SOP) which has been established and is certainly applicable by default and is permanent. Standard Operating Procedures have been established jointly between all staff, assistants, and a member (Commissioner) Ombudsman Makassar. Standard Operating Procedures used as a basis in working for any personnel, including the offense of handling the reported community. In the Standard, Operating Procedures of responsibility includes the authority and functions of each field and the Ombudsman personnel Makassar.

Makassar city Ombudsman as an institution whose role is to receive reports and complaints from the public would have to demonstrate its performance through the acceptance and settlement of the problem through better coordination between the complainant with the reported rapid, precise and accurate. Based on the statement of Makassar City Ombudsman Commissioner who said that:

Every case that goes to the ombudsman Makassar always accepted and processed rapidly by the standard mechanism operational troubleshooting procedures that already exist, so that any problems that enter must rapidly be completed, and if they cannot be resolved as quickly as most complainants can identify the process, and thus the communication between the reporting by the ombudsman is not interrupted at any time, and they can monitor the progress report, (Interview: June 20, 2014). 
As one of the main evidence to measure the performance of OKM, in the process of receiving reports from the public the city of Makassar, then the following can be seen in the following table:

Table 1. Some complaints coming into OKM in 2013

\begin{tabular}{|c|c|c|c|c|c|}
\hline No & \begin{tabular}{|l|} 
Month report \\
\end{tabular} & Number of Reports & Case Type & Reported & Description \\
\hline 1 & 2 & 3 & 4 & 5 & 6 \\
\hline 1 & January & 6 cases & $\begin{array}{ll}\text { 1. } & \text { Service-SIU protracted. } \\
\text { 2. } & \text { Sales LKS Sudirman III Elementary } \\
\text { School. } \\
\text { 3. } \\
\text { 4. } \quad \text { The emplaints Total Tax out of tune. } \\
\text { not conform. } \\
\text { 5. Information is inarticulate and ill- } \\
\text { transparent. } \\
\text { 6. } \quad \text { Family Card protracted. }\end{array}$ & $\begin{array}{l}\text { Headman Lembo. } \\
\text { Principal SD Sudirman III. } \\
\text { Tax office. } \\
\text { Labor offices. } \\
\text { Bank Central Asia. } \\
\text { Staff Head of Bt Ala. }\end{array}$ & $\begin{array}{l}\text { Not Continue } \\
\text { Finish } \\
\text { Not Continue } \\
\text { Not Continue } \\
\text { Not Continue } \\
\text { Finish }\end{array}$ \\
\hline 2 & February & 3cases & $\begin{array}{ll}\text { 1. } & \text { Cost letter domicile is not } \\
\text { appropriate. } \\
\text { 2. Land Certificate protracted (three } \\
\text { Years). } \\
\text { 3. } \\
\begin{array}{l}\text { Payment of the missing vehicle } \\
\text { registration. }\end{array}\end{array}$ & $\begin{array}{l}\text { Headman Mannuruki. } \\
\text { Headman Mc.Sombala. } \\
\text { One Roof System (SAMSAT) of } \\
\text { duplicate parts. }\end{array}$ & $\begin{array}{l}\text { Finish } \\
\text { Finish } \\
\text { Finish }\end{array}$ \\
\hline 3 & March & 4 cases & $\begin{array}{ll}\text { 1. } & \text { Service dissatisfied. } \\
\text { 2. } & \text { A transparent copy of the letter } \\
\text { morbidly ground. } \\
\text { 3. } & \text { Handling IUJK protracted. } \\
\text { 4. } & \text { Payment SITU / SIUP. }\end{array}$ & $\begin{array}{l}\text { Office layout. } \\
\text { Village staffs } \\
\text { Balng Baru. } \\
\text { Ekbang city } \\
\text { Government } \\
\text { Head of sub } \\
\text { District Mamajang. } \\
\end{array}$ & $\begin{array}{l}\text { Not followed up } \\
\text { Finish } \\
\text { Not followed up } \\
\text { Recommendation }\end{array}$ \\
\hline 4 & April & 6 cases & $\begin{array}{ll}\text { 1. } & \text { Service permits protracted operation. } \\
\text { 2. } & \text { Financial Accountability RW } 11 . \\
\text { 3. } & \text { Water flow Loss PDAM. } \\
\text { 4. } & \text { Maladministration replacement } \\
& \text { certificate. } \\
\text { 5. } & \text { Payment of Electricity jumps. } \\
\text { 6. } & \text { No Notification SPPT. } \\
\end{array}$ & $\begin{array}{l}\text { Department of Education Makassar } \\
\text { Barombong headman } \\
\text { DEV. Mitra Mas Principal SMKN } 5 \\
\text { PLN Ahmad Yani. } \\
\text { Headman Karuwisi north. }\end{array}$ & $\begin{array}{l}\text { Finish } \\
\text { Not Completed } \\
\text { Not followed up } \\
\text { Finish } \\
\text { Finish } \\
\text { Not followed up }\end{array}$ \\
\hline 5 & May & 1 case & 1. Change Letter F Book with letter C Book. & $\begin{array}{l}\text { Head of sub district } \\
\text { Panakkukang }\end{array}$ & clarification \\
\hline 6 & June & 2 cases & $\begin{array}{ll}\text { 1. } & \text { Services slow DTRB office. } \\
\text { 2. } & \begin{array}{l}\text { Passengers Losses due to time BP } \\
\text { difference. }\end{array} \\
\end{array}$ & $\begin{array}{l}\text { DTRB and regional companies } \\
\text { Lion Air }\end{array}$ & $\begin{array}{l}\text { Clarification } \\
\text { Not followed up }\end{array}$ \\
\hline 7 & July & 6 cases & $\begin{array}{ll}\text { 1. } & \text { Do not get health care with real } \\
\text { eyes. } \\
\text { 2. The test results are not junior high- } \\
\text { school students are not shown. } \\
\text { 3. Payment of the maintenance of the } \\
\text { certificate by the headman. } \\
\text { 4. Service Health Insurance is not } \\
\text { transparent. } \\
\text { 5. Delays poor service. } \\
\text { 6. } \quad \text { Services BTN protracted. }\end{array}$ & $\begin{array}{l}\text { BKMM } \\
\text { Junior High School (SMP) } 10 \\
\text { Head tamamaung } \\
\text { Askes Reg.Makassar } \\
\text { Head Maccini } \\
\text { Bank BTN }\end{array}$ & $\begin{array}{l}\text { Finish } \\
\text { not completed } \\
\text { not completed } \\
\text { Finish } \\
\text { Finish } \\
\text { Finish }\end{array}$ \\
\hline 8 & Agustus & 4 cases & $\begin{array}{l}\text { 1. Prohibition of students enters high } \\
\text { school executive. } \\
\text { 2. There may be a certificate from the } \\
\text { National Housing Authority. } \\
\text { 3. Headman refuses a signature } \\
\text { certificate. } \\
\text { 4. } \quad \text { Care drugs are not satisfactory. }\end{array}$ & $\begin{array}{l}\text { Senior High School (SMA) Eksekutif } \\
\text { Head Perumnas BTP } \\
\text { Head Antang } \\
\text { Puskesmas Antang }\end{array}$ & $\begin{array}{l}\text { Finish } \\
\text { On Process } \\
\text { Not followed up } \\
\text { Finish }\end{array}$ \\
\hline 9 & September & 5 cases & $\begin{array}{l}\text { 1. Charge the course fee of Rp } 100,000 \\
\text { per student. } \\
\text { 2. Recording meter PDAM not } \\
\text { appropriate. } \\
\text { 3. Issuance of certificates is } \\
\text { complicated. } \\
\text { 4. Payment of a fee by the school } \\
\text { committee. } \\
\text { 5. Demolition lods without }\end{array}$ & $\begin{array}{l}\text { SDN melayu } \\
\text { PDAM Andalas } \\
\\
\text { BPN Makassar } \\
\text { SMAN } 18 \text { Makassar } \\
\text { Melati/Prsd.pasr. }\end{array}$ & $\begin{array}{l}\text { Finish } \\
\text { not completed } \\
\text { Finish } \\
\text { On Process } \\
\text { Not followed up }\end{array}$ \\
\hline
\end{tabular}




\begin{tabular}{|c|c|c|c|c|c|c|}
\hline No & Month report & Number of Reports & & Case Type & Reported & Description \\
\hline \multirow[t]{2}{*}{1} & 2 & 3 & & 4 & 5 & 6 \\
\hline & & & & compensation. & & \\
\hline 10 & October & 6 cases & $\begin{array}{l}2 . \\
3 .\end{array}$ & $\begin{array}{l}\text { The salary below the minimum } \\
\text { wage. } \\
\text { Objection invitation Malay headman. } \\
\text { Housing land certificate has not been } \\
\text { issued. } \\
\text { There is negligence against the } \\
\text { hospital. } \\
\text { Care village administration was not } \\
\text { optimal. } \\
\text { Help BLSM morbidly transparent. }\end{array}$ & $\begin{array}{l}\text { Sinar makmur Store } \\
\text { Head Melayu Baru } \\
\text { Perumnas BTP } \\
\text { RSU Labuang Baji } \\
\text { Head Parangtambung } \\
\text { Head Bunga Ejayya }\end{array}$ & $\begin{array}{l}\text { Not followed up } \\
\text { Not followed up } \\
\text { Not followed up } \\
\text { Not followed up } \\
\text { not completed } \\
\text { Finish }\end{array}$ \\
\hline 11 & November & 2 cases & $\begin{array}{l}1 . \\
2 .\end{array}$ & $\begin{array}{l}\text { BPN cannot issue a certificate. } \\
\text { Payment of the School Committee } \\
\text { since its inception. }\end{array}$ & \begin{tabular}{|l|} 
BPN Makassar \\
Committee SMAN 5
\end{tabular} & $\begin{array}{l}\text { not completed } \\
\text { not completed }\end{array}$ \\
\hline
\end{tabular}

Data by OKM Makassar, 2013

Based on the data recorded in Table 1 above, it can be seen that the complaint received during the year 2013 is not too much, with only 46 cases, so that when averaged, each month is only about 3 to four cases. The low number of cases of complaints coming into OKM Makassar, due to several reasons, among others, still less socialized about the existence and role of the ombudsman Makassar, other than that the cause is people still lack confidence in the ability of OKM in mediating and resolving the issue of maladministration that occurred in Makassar.

The statement above is reinforced by the informant, who said that lack of people who report complaints about maladministration experienced because it is still largely of our society who do not know of the existence of OKM and whatever the authority (Bhr. March 2014). From some 46 cases that went into OKM, which can be resolved or mediated are a total of 18 cases, while cases were not followed up are as many as 21 cases.

The number of cases were not followed up by OKM not due to the inability OKM to complete, but is caused by several factors, namely incomplete data attached by the Complainant was supposed to be a prerequisite of a report to be followed up, while having confirmed and invited back the complainant, they generally do not come to complete the report file, and thus the OKM not follow up in the form of problem-solving, but just make a closing submission to the complainant.

Another thing that causes so many cases the reports are not completed or followed up, because the problem is not the authority. For cases that are in the process of mediation is seven cases, which referred to the case while in the process of mediation is the temporary OKM shall summon the complainant to clarify and complete its report, and the reported party was invited to give an explanation or clarification to the OKM.

From the above, explanation can be concluded that the performance of OKM Makassar to receive reports or complaints from the public of the existence of maladministration in the case of public services, can be considered good enough, because it was done according to the procedures and standard mechanism, although not all reports received can be resolved, since not all OKM reports to meet the requirements of the administrative or outside authority to be processed and acted upon by Ombudsman Makassar (OKM).

\subsection{The quality of service to the community government agencies after the complaint to the ombudsman Makassar.}

The final goal of surveillance run by the city of Makassar is the ombudsman the changing patterns of behavior and attitude of public servants towards better characterized by increasing responsive and transparency of public servants in providing services to the public. From the research that has been conducted against the ombudsman Makassar, among the many problems posed by the complainant, largely from the report have been getting the follow-up of the ombudsman, if any problems or statements that are not followed up by the ombudsman, it is because outside the authority of the ombudsman.

Based on interviews of informant's rapporteur, in general, they state that, in principle, the agencies that reported carrying out what has been recommended ombudsman, this statement is in line with statements of informants stating, "we never take care of mailing a land certificate in the office of National Land Agency, but it is complicated, and after Our report to the ombudsman turns out, we called to immediately resolve and the results have been completed "(MK, March 2014).

After confirmation of several agencies reported the service process that seemed slow and not transparent in general they admit that it is indeed the case, despite the various justifications. One statement from the institution reported 
that "in fact, fact what was presented by the complainant indeed there is a delay in the distribution of rice for the poor, but the real mistake was not entirely is due to our side, but it happened because of the distribution of over late, so we were too late in the process distribution, and it is only once after that never again, as we had anticipated earlier "(AM, April 2014).

Furthermore, reported another never interviewed by the author regarding drug services are unsatisfactory, ever performed on a patient, the reported said that "it was he had done but not the intentional factor, and he has made a clarification on the complainant and to the ombudsman and the results both sides.

\section{Conclusion}

1. The role of an ombudsman Makassar in carrying out its duties and functions quite effectively when viewed performance in receiving reports and / or complaints from the public quite effectively.

2. The role of the Ombudsman Makassar to respond to and / or following up complaint's communities to take quite effective when seen from the performance of the service unit / government agencies Makassar increased and changes towards more tubs.

\section{References}

Ahdiyana, Marita. (2008). Accountability mechanisms LOD of Yogyakarta Province. Jurnal Spirit Publik, 4(2), pp. 169 - 184.

Anonim. (2008). Handbook Ombudsman of Makassar. Makassar: OKM.

Bungin, Burha. (2010). Qualitative Research (communication, economics, public policy and other Social Sciences). Jakarta: Kencana.

Dwiyanto, Agus. (1995). Public Organization Performance Assessment. Yogyakarta: Universitas Gadjah Mada.

Dwiyanto, Agus. (2001). Public Bureaucracy Reform in Indonesia. Yogyakarta: Pusat Studi Kependudukan dan Kebijakan.

Hartono, Sunaryati CFG., Masturi, Budi., Rochmaeni, Enni., \& Winarso. (2003). Ombudsman Investigation Guide for Indonesia. Jakarta: Komisi Ombudsman Nasional.

Komisi Ombudsman Nasional. (2005). the role of the Ombudsman in the Elimination and Prevention of Corruption and Good Governance Implementation. Jakarta: Komisi Ombudsman Nasional.

Keban, Yeremias T. (2000). Good Governance and Capacity Building as Key Indicators and the focus of Government Performance Assessment. Jakarta.

Masthuri, Budhi. (2005). Introduction to Ombudsman of Indonesia. Jakarta: Pradnya Paramita.

Mas'udi, Masdar F., Winarso., Masturi, Budhi., Agus I, Patnuaji. (2006). Prospects, Opportunities and Challenges of Development of Regional Ombudsman in Indonesia. Jakarta: Kerjasama KON dengan Commonwealth Ombudsman Australia dan AusAID.

Mulia, Musdah. (2001). Islamic Political of Husayn Haykal. Jakarta: Paramadina.

Miles, M. B., \& Huberman, M. (1992). Analysis of Kualitatif Data. (Translated by Tjetjep Rohendy Rohidy). Jakarta: UI Press.

Nasrullah. (2002). Optimizing the Role of KONI in Order to Achieve Good Governance. Paper on Diskusi Bulanan Dosen Fakultas Hukum. Yogyakarta: Universitas Muhammadiyah Yogyakarta.

Ombudsman Internasional. (2002). an Antology. Jakarta: Komisi Ombudsman Nasional.

Patarai, Idris. (2010). Regional Ombudsman Institutions Performance Effectiveness and accountability of local government Public Yogyakarta Special Region. (Dissertation). Makassar: Universitas Negeri Makassar.

Sipayung, P.J .J. (1989). Officials As Candidate Accused In Administrative Courts. Jakarta: CV. Sri Rahayu.

Steers, R.M. (1980). Efectiveness Organization. Jakarta: PPM

Sumardjono, Maria S.W. (1989). Guidelines for Preparation of Proposed Research. Yogyakarta: Universitas Gajah Mada.

Wibawa, H. (2010). Oversight Ombudsman against the Operator of State and Government. Semarang: Universitas Diponegoro. 